\title{
Indian Tigers, Chinese Dragons: Uncertainty, Risk, And Entrepreneurial Behavior
}

Hemant Rustogi, University Of Tampa, USA

F. Frank Ghannadian, University Of Tampa, USA

Jin Wang, Westminster College, USA

\begin{abstract}
This paper examines entrepreneurship in two of the modern marvels of emerging markets: China and India. Both of these countries have immense economic problems, but are growing at a strong rate. These growth rates are also creating powerful entrepreneurial forces. Which region is going to develop more entrepreneurs or attract foreign investments quicker is the key to a race between the two countries. This paper presents a conceptual framework that shows the relationships between uncertainty, risk, and entrepreneurial behavior, and also the problems and successes of entrepreneurs, with illustration of three cases from each country. The paper discusses similarities and differences in entrepreneurial risk taking between the two countries and presents key factors that impact entrepreneurial activity in these two countries. This paper has implications for companies seeking new markets, or business partners in these nations.
\end{abstract}

Keywords: Uncertainty; Entrepreneurship; Risk; China; India

\section{INTRODUCTION}

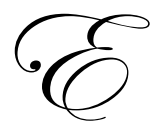

ntrepreneurship is the path to economic development. Over a century ago, Schumpeter discussed entrepreneurship as a necessity for successful capitalism and the growth of modern economic structures. Two of the marvels of modern economic development are China and India. These two countries are home to $40 \%$ of the world's population. Their individual and collective successes will impact the global economic environment and change the world economy that we know today. China thrives by the amount of FDI it receives, which leads it to have an export led economy. India's FDI has been far lower, mainly due to mistrust of foreigners and expatriates' lack of confidence in the motherland; however, this has started to evolve. Instead, entrepreneurship has been nurtured; creating an environment in India that favors small businesses and innovation. The Global Entrepreneurship Monitor reports that $12.5 \%$ of the Indian population was involved in opportunity-based ventures as compared to 5.5\% of the Chinese working population. Many restrictions in China have been designed to prevent competition from private entrepreneurial firms against the state owned enterprises of China. In the past ten years, India's government has backed away from closely managing the economy. Khanna (2004) argues that India has empowered its independent entrepreneurs, while China has "shackled" them. An example of this phenomenon of growth has been that in the Forbes 200 list of the world's best small companies, 13 of them were Indian, while 4 of them were Chinese. On the other hand, China's economy has been growing at an unprecedented rate of between $9 \%$ and 10\% per year since 1978, which is an even higher rate than India's economy rising at a rate of over 6\% per year. One plausible explanation for this difference is that the Chinese government nurtures economic activity and welcomes foreign direct investment, while the Indian government is significantly more cautious on both counts.

This paper looks at the conceptual model of difficulties encountered in translating uncertainty into risk in the two countries and analyzes the case of three successful entrepreneurial firms in each country. Since India's entrepreneurs are more woven into the fabric of the socioeconomic part of society, we ask the following question: will India's economy eventually surpass China's or will the gap between the two widen? There are two sets of 
arguments: those who insist that India will surpass China, and those who claim that China is in the process of creating entrepreneurial support organizations, which will keep growing faster than India. This paper provides some policy prescriptions to propose future research in this area, and provides insights for companies seeking business partners and market access in these two nations.

\section{THE ENTREPRENEURIAL ENVIRONMENT IN INDIA \& CHINA}

Koveos and Tang (2007) contend that India and China have taken very different political paths to become part of the global economic elite. However, both countries share an economic freedom that has allowed entrepreneurship to thrive. China got a head start in the late 1970's, while India benefited from radical reform in 1990 that paved the way toward a market driven economy. The global economic landscape has been dramatically shaped by the emergence of India and China as major players over the past twenty years. Over this time period, per capita GDP has more than doubled for India while China has enjoyed seven-fold growth, according to the World Bank's World Development Indicators (Bosworth and Collins 2008). More recently, between 1993 and 2004, China has realized greater levels of output growth than India (9.7\% to $6.5 \%)$ and output per worker (8.5\% to $4.6 \%)$ (Bosworth \& Collins, 2003). These growth prospects are likely to continue for both countries in services, trade, and investment flows. China, however, has been a greater beneficiary of foreign direct investment (FDI) than India in recent years ( $\$ 50$ billion to $\$ 5$ billion), as India has been reluctant to embrace FDI due to its protectionist behavior. However, it is recommended that the data be viewed with caution, as Rawski (1998) questions the validity of the growth data for China and contends that growth rates are about half those that have been reported, as these numbers have been subject to government falsification. Even though this may be true, India lags behind China in world development indicators and must make a significant investment in infrastructure, communication technology, innovation, and education to narrow the gap (Jauhari, 2007). According to Business Monitor International (2010), political, institutional, and operational risks in both countries create unique challenges for entrepreneurial activity. Corruption and bureaucracy continue to hinder opportunity. This economic growth provides the backdrop for entrepreneurial activity in these two countries. Tarun Khanna (2007), a leading expert on entrepreneurship in India and China, argues that entrepreneurs are thriving in these two countries, though the opportunities and challenges are significantly different as they relate to "access to capital, freedom and reliability of information, governmental involvement and infrastructure" (Lagace, 2007).

According to Khanna (2007), the degree and type of governmental involvement is one key difference between these countries. The author makes the case that in China, "the government is often the entrepreneur," as it is difficult to find Chinese firms of any reasonable size without key government involvement. In contrast, India ventures are primarily vested in the private sector and are handicapped, for the most part, by a largely inefficient government. The occasional flashes of governmental brilliance still abound.

The Indian infrastructure is inadequate at best, and unable to keep up with the needs of its people. The larger cities in particular are severely handicapped with daily power outages, inadequate water supply, a broken transportation and highway system, and a limited information system. China is marginally better than India in some of these areas but scores lower points than India on the credibility of its business media and financial market information (Khanna 2007). However, Indian companies too have been guilty of fraud and error in the past.

Even though China boasts higher education levels at the secondary and post-secondary levels relative to India, on the strength of its scientific and computer engineering training, India appears to be better prepared to meet global challenges relative to China as they relate particularly to software development (Jauhari 2007). India lags behind China as it relates to its information infrastructure, as connectivity is a problem. This advantage has allowed China to provide better products for the global market (Jauhari 2007).

\section{ENTREPRENEURSHIP IN INDIA}

While it is clearly easier to start entrepreneurial ventures in the big cities due to the availability of infrastructure and services, rural entrepreneurial activity continues to thrive. According to Ramadorai (2008), "it is a myth that entrepreneurship or entrepreneurial skills are limited to those people starting (large) companies." The author contends that entrepreneurship is booming in India though it does not have the appropriate ecosystem to 
support it. An entrepreneurial ecosystem is nothing more than a "system of interconnected stakeholders institutions and individuals - whose close linkages enable efficient production, diffusion, and the use of new and economical useful knowledge" (Ramadorai, 2008).

India has over 13 million shops (retail outlets) and 4 out of 5 are family owned. The many Indian millionaires who struck gold in Silicon Valley in the United States changed the entrepreneurial landscape in India dramatically. New college graduates in India are now more likely to gain practical experience with large companies and start out on their own. A joint study conducted by TiE and KPMG measuring the Entrepreneurial Confidence Index (ECI) in 10 Indian states shows that Indian entrepreneurs are "bullish" on the ecosystem that supports such activities, though risk capital and government issues did not get passing grades (Ramadorai, 2008).

Education plays a pivotal role in sparking, nurturing, and fueling the entrepreneurial spirit. Schools and colleges should serve as the labs for developing and testing entrepreneurial ideas as Ramadorai (2008) rightfully states that "opportunity evaluation, risk taking, raising and leveraging resources, communications, and sales are survival skills; and these cannot be imbibed through an intensive dose later in life."

The Global Entrepreneurship Monitor published a study in 2006 indicating that 1 in every 10 Indians is engaged in entrepreneurial activity and $70 \%$ of these individuals are engaged in opportunity-based as opposed to need-based entrepreneurship (Desai, 2007). Women entrepreneurs have played a growing role in the Indian economy. Most took on this role as it allowed them to contribute to their family income when few other opportunities existed. Another catalyst for female entrepreneurial activity was their ability to gain economic independence and free themselves from the ancient caste and male dominated social systems (Handy, Ranade, \& Kassam, 2007).

One of the key investment markets in India continues to be the business process outsourcing industry (BPO). This industry has experienced phenomenal growth at a rate. During 2004 to 2005 growth peaked at a rate of $50 \%$, the following year growth was 38\%, and in 2009 the industry grew 16\% (Prabhakar, 2011). The BPO market was estimated to be $\$ 16.9$ billion as of 2011, with India holding over $37 \%$ of those revenues (SiliconIndia, 2011). There are approximately 400 companies operating in the BPO realm serving international corporate giants such as British Airways, American Express, and General Electric. According to the New York Times, there are over 500 thousand software developers in India and as of 2001, the Indian software industry was grossing close to $\$ 9$ billion a year. Gupta (2001) argued that "India needs entrepreneurs" and suggested 4 areas of focus to allow this to happen -creating the right environment, access to the right skill set, access to capital, and a network support system. The prescription for success is not unique, but necessary for long term global success.

\section{ENTREPRENEURSHIP IN CHINA}

The entrepreneurship environment in China was suffocated before 1978 for several reasons. First, the communist political ideology ended the private ownership of production and businesses. Second, publicly owned enterprises suffered from a planned economy. Furthermore, war and unrest for many decades ruined domestic industries, minimizing saving and investment.

The entrepreneurship environment in China has changed for the better over the last 30 years. Since the late 1970's, small and medium sized enterprises (SME's) have flourished in China. There are different paths to ownership (private, collective, and public), and different enterprise structures (proprietorship, partnership, and corporations).

Today the SME's play an important role in the Chinese economy. The average growth rate during the $10^{\text {th }}$ five-year planning period was $9.5 \%$; the average growth rate of SME's was $28 \%$. These SME's account for $99 \%$ of total firms about $60 \%$ of China's GDP, $50 \%$ of China's total taxes, and $75 \%$ of non-agriculture jobs. SME's have also become more prominent in innovation; they contributed $65 \%$ of patents, $75 \%$ of innovation, and $80 \%$ of new products. Additionally, 70\% of China's well-known products are produced by SME's. Some SME's have been actively involved in imports and exports. By the end of 2006, SME's total imports and exports reached \$243.6 billion, a 46\% growth over 2005, and two times China's growth rate of 23\% (Heing, 2012). 
The fast and impressive changes of SME's in China speak to two basic factors: the Chinese are very entrepreneurial, and the entrepreneurship environment in China has improved tremendously. However, there are some major challenges for the future development of SME's in China.

- $\quad$ Dependence on low price competition: Many SME's have depended on cheap labor, land, resources, and low price for survival. This has led to high environmental cost and low quality of technology and management.

- Low quality of labor force and low level of management: Chinese SME's cannot compete more successfully in labor intensive and service industries. On the other hand, they have over-invested in the resource and raw materials industries, (which require a high level of capital investment,) and they have under-invested in high-tech and new industries.

- Uneven regional development: SME's are highly concentrated in the eastern coastal areas and much less in the central and western areas.

The Chinese government has made economic development its first priority in hopes that a sustained economy will yield opportunities to address other challenges, such as political reform, environmental degradation, social and economic inequalities, and societal unrest. In order to further enhance and sustain the growth and development of SME's the Chinese government is trying to:

- $\quad$ Reduce restrictions on issuance of business permits to encourage SME's to enter the field of mineral mining and extracting industries.

- $\quad$ Help SME's enter the capital market.

- $\quad$ Develop more effective systems and ways to regulate SME's.

- $\quad$ Improve banking for SME's by developing more favorable terms and policies to enhance the support for SME development and help with SME's venture investment. (Subroto, 2011)

\section{THE CAPITAL MARKETS IN INDIA AND CHINA}

In general, an efficient capital market is an avenue for entrepreneurs to gain the seed capital necessary to launch or improve their business. India has the advantage in many ways over China in the area of capital markets. First, the legal system favors personal property rights. The prevalence of English as the language of choice in business and a democratic political structure and mindset gives India the advantage of being a more efficient market than China. The Bombay Stock Exchange (BSE), established in 1875, is located on Dalal Street in Mumbai. As of August 2007, the BSE had 4,800 listed companies. Its average daily trade volume is 1 million. It is the fifth largest exchange in the world, with market capitalization of US \$1.61 trillion. Its annual growth rate is about $18 \%$.

There are 23 stock exchanges in India; 21 of these exchanges are regional stock exchanges. The remaining two exchanges, the Bombay Stock Exchange (BSE) and the National Stock Exchange (NSE), are national level stock exchanges.

The other significant exchange in India — the National Stock Exchange (NSE)—-was incorporated in 1992. The average daily turnover in the CM Segment during 2006-2007 was nearly US \$1,792 million. In October 2007, the equity market capitalization of the companies listed on the NSE was US $\$ 1.46$ trillion. With 1587 listings, the NSE's growth rate is about $15 \%$. The regional stock exchanges began clustering in 1894 and in the 1980s the majority of the regional stock exchanges were incorporated.

In China, even with all the glass corporate parks and state of the art facilities, the market is still not liquid. Even though the aim was to make Shanghai the leading global financial center, the experience of 2001- 2005 told a different story. The market collapsed and later the removal of the communist party leader did not help to provide an atmosphere conducive of market growth. The Shanghai Stock Exchange, located in Shanghai, opened in 1891; it was re-established in 1990 after being suspended in 1949. As of February 2008, 861 companies were listed on the SSE and the total market capitalization was US $\$ 3,241.8$ billion. Many of the major indices had a combined annual growth rate of $9 \%$. 
The other major market is the Shenzhen Stock Exchange, a national stock exchange that provides a venue for securities trading. The Shenzhen Stock Exchange has a market capitalization around US \$122 billion. On a daily basis, around 600,000 deals trade on this exchange. This market is growing due to its proximity to Hong Kong. The Shenzhen Exchange launched the blue-chip composite index in January 1995. It also directed a subsidiary, the Shenzhen Securities Information Co., to launch the Shenzhen Stock Exchange 100 Index on the first trading session of 2003. The new index is composed of major firms such as Shenzhen Development Bank, property developer China Vanke Co Ltd, and Guangdong Electric Power Co.

\section{ENTREPRENEURS AND RISK TAKING}

The understanding of risk-taking in finance, economics and decision-making has been well documented. These rational decision makers make risk-taking decisions vital to maximizing their expected utility with a set of risky payoffs. These choices are different when one looks at the various behaviors that individuals have across national borders.

The best description and examination of risk and uncertainty was developed by Knight (1921), where he argued that entrepreneurs under uncertainty with unquantifiable probability (versus risk with quantifiable probabilities) were to receive returns superseding normal returns. Knight theorizes three situations which are useful for the entrepreneurial process: 1) having a priori mathematical probability, 2) statistical inferential probability information, 3) no basis for classification of risk. Knight's response to uncertainty was to reduce it to risk. Knight would see a rational entrepreneur converting an uncertain situation to a situation of risk, which allowed computational returns and adequate compensation for capital. Venturing into uncertainty, where there is only intuition and opinion or hunch without some formal expectations, would not be rational. Obviously, John Maynard Keynes' book, "A Treatise on Probability" (1921), published about the same time, mentioned that he also believed that assigning probabilities to future states was beyond economic theory. Most entrepreneurial research conducted since that time has focused on entrepreneurial rationality as an investment decision made with probabilistic assumptions. While Littlefield (1986), Buchanan and Vanberg (1991), and Sarasvathy et al (2003) have worked on development risk with entrepreneurial processes, Miller (2007) advocates three entrepreneurial processes:

1) Opportunity recognition: This is the modernistic approach to understanding risk. Here, entrepreneurs draw upon their own limited information and make a subjective estimate of the future states before they make business decisions. In this state, the rational entrepreneur seeks to maximize returns and minimize risk at the same time. The risk bearing parties may develop contracts that allocate risk and provide compensation for the risk incurred.

2) Opportunity discovery: This is where the entrepreneur ventures into the unknown. There are unexplored possibilities that make business sense and there is a lack of knowledge associated with those possibilities. In this situation the search process is based on partial knowledge of probabilities. This is an environment where errors occur and opportunities are explored sequentially and not concurrently.

3) Opportunity creation: The opportunity here is brought to picture as a result of the efforts developed by the entrepreneur. The entrepreneur, as opposed to discovering opportunities, has created an environment for a potential venture. Of course these activities, based on human actions, create a nondeterministic outcome. In some cases, due to the construction of this opportunity, the entrepreneur is ignorant of interdependencies to others' actions. Many inventors are often beaten to the patent office by another inventor even though they work independent of one another.

Miller contends that most utility models are good with handling opportunity recognition but weak with handling opportunity discovery and opportunity creation. Wu and Knott (2006) have distinguished two additional aspects of this discussion by adding that there are two sources of uncertainty in entrepreneurial ventures. First, there is a great uncertainty about market demand. How do entrepreneurs know that there is a market for their products, especially in those markets where market data is not available (but even when data is present, its quality is suspect)? Entrepreneurs in most cases express their fear of market demand and are generally risk averse and pessimistic in this category. This idea of fear of risk of demand and price uncertainty which would affect profits is a classical issue that has been debated by economists for over two centuries. The second area of uncertainty in entrepreneurial activities is uncertainty within one's own entrepreneurial activities. Is it possible that entrepreneurs are risk averse in demand 
uncertainty but bold and overconfident in their own abilities? If this notion is true, then entrepreneurs are taking further risk. There may be a biased anticipation of their own ability to handle unforeseeable events. Wu and Knott (2006) believe that entrepreneurs (at least in the banking industry) are better suited to take on economic risk when the degree of performance dispersion (overconfidence) is greater than (and therefore can compensate for) risk aversion.

The differences and similarities in entrepreneurial behavior in India and China are driven by culture, history, government regulation (or the lack thereof), and the economic environment. However, when the dust settles, it boils down to how this uncertainty can be translated into risk. It is the efficacy of understanding this conversion that has promise on who can cross the finish line first. The figure below articulates and proposes the conceptual relationships between uncertainty, risk, and investment. Greater investments create an environment more conducive to entrepreneurial activities.

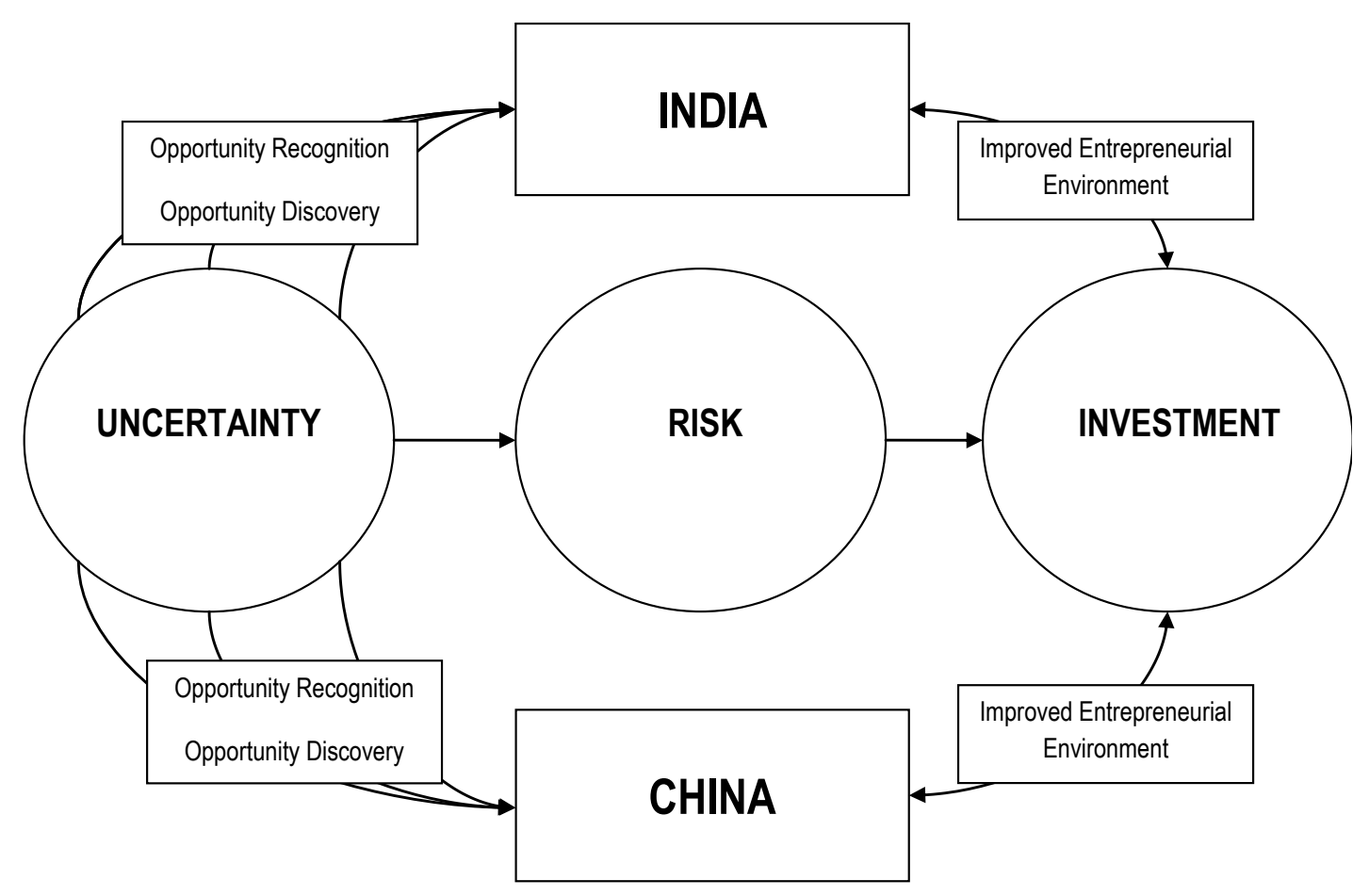

\section{FACTORS IMPACTING UNCERTAINTY AND RISK IN INDIA AND CHINA}

Deshpande, Farley and Bowman (2004) conducted an empirical study and found that India and China excelled in entrepreneurial dynamism, risk-taking, leadership, and innovation, and exhibited a strong emphasis on growth. Given market conditions, which are impediments to the success of Indian versus Chinese entrepreneurs, the issue will be how to transcend the boundary that bridges the gap between uncertainty and risk-taking in these two countries. Differences in entrepreneurial attitudes are driven by country specific perceptions of demand, ability, uncertainty and perceptions of opportunity in the workplace. The authors propose that the following factors impact entrepreneurial perception of uncertainty, opportunity, and ultimately risk.

- $\quad$ Attitudes towards the future: Fatalism of the possibilities being decided divinely in India. China's aging population is a problem and will lead to the 4-2-1 problem; every child will have to take care of 4 grandparents and 2 parents. By 2040 a third of the Chinese population will be 60 and over. In this area, India will have a younger population for decades into the $21^{\text {st }}$ century. 
- $\quad$ Lack of regulation and red tape: In India there are far fewer restrictions on business licenses than in China. However, India's tariff rate is higher than China's. Also, in India hiring and firing employees for companies with 100 or more employees are more restricted. The World Trade Organizations' pressures to correct this seem to be less potent in India than in China.

- $\quad$ Large businesses versus small businesses: In China, there are more large firms competing than in India. Smaller firms are larger in number in India than in China.

- Corruption is rampant in both places: In this area there are more similarities between the two countries than differences. Both bribery and corruption are rampant in different sectors and across industries in both countries.

- $\quad$ Lack of resources and funding: Loans are much harder to come by in India than in China. The banking system for loans is not as developed in India as it is in China.

- $\quad$ Large capital versus small capital: It is much more difficult in India to process and organize large loans and interest rates are cost prohibitive.

- $\quad$ Differences of women entrepreneurs: Women have traditionally been homemakers in India as opposed to China, but there may be a cultural block in both countries for the advancement in this area.

- $\quad$ Lack of reliable data: The available data for entrepreneurs is scant at best. There are multiple government agencies that have unreliable data on industries. Academic research conducted by universities and the private sector is providing more information, but there is not enough historical market data that should be used to drive business decisions.

- $\quad$ High propensity for risk taking: The Indian entrepreneur, due to his cultural orientation, is a much higher risk-taker than his Chinese counterpart. In contrast, China has done much better in attracting foreign investments. The uncertainty of enforcement of property rights and the lack of ingredients of an entrepreneurial environment has made China less conducive to the development of entrepreneurship. Surveys of executives show that only $3 \%$ thought China's economy is open for entrepreneurial activity (Smith, 2008). Barriers to enterprise are cited with $83 \%$ of respondents indicating aversion to risk and failure and $69 \%$ believing government legislation is a barrier to enterprise. Some have even called this form of enterprise as "commanding-heights capitalism" versus a fully functioning market economy with excessive interference by government as a true barrier.

- $\quad$ Education: In China the literacy rate is greater, but overall, the quality of higher and upper level education is superior in India. The prediction that by 2050 India's population will reach 1.6 billion, ahead of China's 1.4 billion, means that an extra 200 million people in India will have to be educated, housed, and fed.

- Infrastructure for conducting business: The state of infrastructure is far better in China than India. The quality of business environment is rated higher in India, where the World Economic Forum's competitiveness report for 2006 shows that China (ranked $54^{\text {th }}$ ) is behind India (ranked $43^{\text {rd }}$ ).

- $\quad$ Tax system: Both countries have a tax system that penalizes individual success and does not take into account individual differences.

\section{ENTREPRENEURIAL SUCCESS CASES IN INDIA}

Historically, India is known for its mystics and snake charmers, beggars and poverty, and for its diverse culture bogged down by the tenants of the caste system. Against this backdrop India has quietly bred some of the most innovative companies in the world driven by a keen entrepreneurial spirit and a never-say-die attitude. Here are the studies of three such companies.

\section{Hero Cycles}

Brijmohan Lala Munjal migrated to India from Pakistan around the time of partition in 1947. The frightening consequences of partition and the new spirit of self-reliance that came with it created many opportunities for a nation on the move and Mr. Munjal provided the "wheels for it." Started as a bicycle components manufacturing business, Hero started manufacturing bicycles in the late 1950's based on a technological platform acquired from Germany and Japan. In 1971 the company committed to rapid expansion and by 1975 it became the largest bicycle manufacturer in India. 
Driven by a passion for growth, they turned to manufacturing mopeds and captured $35 \%$ of that market by 1983. Soon after they joined hands with Honda of Japan and quietly became the largest bicycle manufacturer in the world and were recognized as such by the Guinness Book of World Records. By the early 1990's Hero was manufacturing motorcycles, and today every second motorcycle sold in India is made by them. They are recognized as the world's largest manufacturer of two-wheel motorized vehicles, selling 3 million bikes in 2005.

The success of the company has been attributed to a number of key factors including their mastery of justin-time inventory systems and the integration of their supply chain by building and owning over 300 ancillary units providing key components for their product lines. In a country riddled with labor unions that can stifle growth, Hero did an incredible job of doing away with organized labor and providing excellent benefits including health care, housing allowances and vacation pay. Diversification was a critical strategic initiative. The company has continued to diversify into areas such as financial services, insurance, and information technology.

The Hero Group's phenomenal growth is the result of constant innovations, a close watch on costs and the dynamic leadership of the Group Chairman, characterized by a culture of entrepreneurship, of right attitudes and building stronger relationships with investors, partners, vendors and dealers and customers. (Hero Honda, 2007)

\section{Infosys}

Infosys is one of the pioneering Indian companies that have changed the way the world looks at Indian business. In 1981, Narayana Murthy borrowed $\$ 250$ from his wife, met with a few friends, and ventured on the path to writing software code and eventually into business process outsourcing (BPO). The company crossed the $\$ 1$ billion revenue mark in 2004, and $\$ 2$ billion in revenue by 2006. Infosys is the first Indian company to be listed on the NASDAQ exchange and to offer stock options to its employees.

Today, Infosys derives about two-thirds of its revenue from the United States, serving corporate clients like Reebok, Visa, Boeing, Cisco Systems, Nordstrom and New York Life. (Dajiworld 2007).

Contrary to the Indian business culture, (historically driven by government control and tax manipulation,) Infosys practiced transparency and adopted a global outlook for its customer base. The success of the company has been driven by developing a scalable strategy, nurturing and leveraging intellectual capital through an intensive mentorship program, making a corporate commitment to knowledge management, and creating an organization structure that facilitates global delivery (Garud, Kumarswamy and Malhotra, 2003). Infosys employs over 100,000 people and is expected to exceed the $\$ 5$ billion revenue mark this year.

\section{AMUL}

It began with two village cooperatives and 250 liters of milk a day... Today AMUL collects, processes and distributes over a million liters of milk and milk products a day...on behalf of more than a thousand village cooperatives owned by half a million farmer members (Indian Diary, 2007)

Previously, the private traders and middlemen who took responsibility for distributing milk exploited Indian farmers. The farmers, operating on small margins, realized that the only way to survive was to market the products themselves. AMUL was established in the 1940's as a union organization of milk cooperatives to eliminate the middlemen and to protect the farmers.

Today, "Everyday AMUL collects 447,000 liters of milk from 2.12 million farmers (many illiterate), converts the milk into branded, packaged products, and delivers goods worth Rs 60 million (\$1.5 million) to over 500,000 retail outlets across the country" (Chandra, 2005).

The success of this $\$ 550$ million national enterprise is driven by an amazing organization structure that encompasses over 2 million farmers in close to 11,000 villages in India. The company adopted a low cost pricing strategy to develop demand, introduced high value products, and created a distribution network of 3,500 distributors and 500,000 retail outlets. The various unions have the autonomy of developing products that sell under the 
umbrella brand, AMUL. The company has made a successful commitment to the sharing of best practices and, given the size and diversity of the farmer network, invested in technology and e-initiatives to help their cause (Chandra, 2005).

\section{ENTREPRENEURIAL SUCCESS CASES IN CHINA}

The following cases are business success stories in the Chinese entrepreneurial arena and will illustrate the potential available in China.

\section{Haier Group}

Mr. Ruimin Zhang, a world-renowned business leader and entrepreneur, founded Haier Group in December of 1984. He started as the Director of the Qingdao Refrigerator Factory, a dying enterprise with huge debt and inability to pay its employees for months. Mr. Zhang and his Vice Director, Mrs. Mianmian Yang, have become such a successful team over the last 24 years that they have transformed an insolvent local manufacturer into a multinational corporation with worldwide sales of over 100 billion Chinese Yuan. As the third largest household appliances manufacturer in the world (following only Whirlpool and GE), the Haier Group operates 30 plants in the United States, Pakistan, India, Italy, and other countries.

Due to his success, Mr. Zhang has been invited to lecture at Harvard University. His successful revitalization of another defunct local electric appliance manufacturer has been included in the Harvard Business School cases. Mrs. Yang has been included in the Fortune and Forbes as one of the top 50 most powerful women in business. Although there are many factors contributing to Haier's successes, Mrs. Yang, now President of Haier, described Haier's rise in four stages by making brand building and corporate culture building its first priority and following a nontraditional expansion strategy of entering the developed markets (Europe and US) before venturing into developing Asian markets. The four stages include development, diversification, internationalization, and globalization.

\section{China Dongyi Shoes Co., Ltd}

Originally known as Wenzhou Dongfeng Shoes established in June of 1986, with total assets about 46,000 Yuan's and less than 20 employees, produced over 20 pairs of leather shoes daily, just like a family shop without much market reputation at all.

In September of 1991, Wenzhou Dongfeng Shoes became China Dongyi Shoes Co. Ltd. Now the company employs over 3,000 employees and owns over 120,000 square meters. The total fixed assets exceeds 500 million Yuan, including 12 assembly lines imported from Italy, producing mostly medium to high quality leather shoes (28,000 pairs per day,) with 95\% exported to international markets, including Russia, East European countries, Japan, Korea, Southeastern Asian countries, United States, Jordan, Western European countries, and African countries. It is one of the top 500 companies in China with total annual sales of more than 300 million Yuan. Studies attributed China Dongyi's successes to the following:

- Leveraging comparative advantages of cheap labor, efficiency arising from division of labor within the industry, scale economies by aiming at general consumers, and specialization (no commodity diversification).

- $\quad$ Export-Oriented Marketing: Although China Dongyi initially focused on the domestic market, it turned to the international market once it learned from a Hong Kong businessman that its products would be very hot in the international market. In developing international markets, China Dongyi developed marketing agreements with Elan, Polo, and Payless, so that its products could be sold through their distribution networks. 


\section{New Hope Group}

In 1982, Mr. Liu Yonghao and his three brothers resigned from their positions with publicly owned enterprises and came to a rural area in Sichuan province to start a new business in the breeding of quails and chickens (perceived by many at the time as a very risky decision). In 1988 the brothers developed a branded hog feed that soon took over the regional market in Chengdu and became a great success in China by 1992. In 1995, the animal-feed business was split to become four groups and Mr. Liu Yonghao became Chairman of New Hope Group. By the end of 1999, New Hope Group had diversified into food processing, high technology, real estate, electronics, and banking and insurance, according to Forbes. New Hope Group has been listed as National Leading Enterprise for Agriculture Industrialization by nine national ministries, the Largest Private Enterprise by the Sichuan Provincial Government, and has been selected twice in the "500 Largest Enterprises in China" with 170 subsidiaries and 35,000 employees all over China and Southeast Asia.

Among other factors, the successes of New Hope Group have been attributed to the Liu brothers' opportunity recognition ability, risk-taking attitude, ability to introduce the best talents and latest concepts, willingness to adopt new and better technologies, and efforts in investing in the industries with high-growth prospects.

\section{CONCLUSIONS AND SUGGESTIONS FOR FURTHER STUDY}

The topic of entrepreneurship in China and India is vast and cannot be described in a single paper or book. However, some of the problems and challenges faced by entrepreneurs in both countries have been revealed in this paper. This paper has shown that the obstacles for entrepreneurs in India versus China remain the circular flow of conversion of uncertainty into risk. In addition, this paper has shown that the more transparent the economy, the quicker the conversion into investment. The data on activities of entrepreneurs will become further developed as these countries progress, and as empirical information becomes available more studies and conclusions will be reached. There is no doubt that both of these countries are dashing toward more capitalism and advancing their developing economies. The final answer of who will surge ahead will mainly depend on government policy of a fair tax system, more democracy, and transparency.

\section{AUTHOR INFORMATION}

Dr. Hemant Rustogi is Chairman of the Marketing Department and the Dana Professor of Marketing at The University of Tampa, $401 \mathrm{~W}$. Kennedy Boulevard, Tampa, Florida 33606. He has published in a variety of journals and written numerous book chapters in a 20 year academic career. The University of Tampa's international business program initiatives have been spearheaded by Professor Rustogi who has been awarded over $\$ 2$ million in matching funds grants by the US Department of Education. E-mail: hrustogi@ut.edu. Corresponding author.

Dr. F. Frank Ghannadian is the Dean and Professor of Finance at the College of Business at the University of Tampa. Previously, he served as Associate Dean and Chief Operating Officer of the School of Business and Economics of Mercer University. He received his bachelor's degree from The University of Tennessee, an MBA from Queens University of Charlotte, and a Ph.D from Georgia State University. Dr. Ghannadian is the author of numerous journal articles and book chapters in the fields of International business and finance. E-mail: fghannadian@ut.edu

Dr. Jin Wang is the Dean of the College of Business at Westminster College in Utah. He was born and raised in China, and earned his BA in Economics from Zhongshan University. He received his MA in Economics from Ohio University, and his Ph.D. in Economics from Kansas State University. He taught at Eureka College and the University of Wisconsin-Stevens Point. Dr. Wang served as the Associate Dean of the College of Letters and Science at UW-SP, College of Liberal Arts and Sciences at Rowan University before becoming Dean of Academic Services at The University of Tampa. His areas of research interest include Sino-American trade and economic development issues in China. E-mail: jwang@westminstercollege.edu 


\section{REFERENCES}

1. Bosworth, B. \& Collins, S. M. (2003). The empirics of growth: An update. Brookings Papers on Economic Activity, 2003(2), 113-206.

2. Bosworth, B. \& Collins, S. M. (2008). Accounting for growth: comparing China and India. Journal of Economic Perspectives, 22(1), 45-66.

3. Chandra, P. (2005, September 3). The extraordinary story of Amul. Retrieved from http://www.rediff.com/money/2005/sep/23spec.htm

4. Child, J. \& Tse, D. K. (2001). China's Transition and its Implications for International Business. Journal of International Business Studies, 32(1), 5-21.

5. Daijiworld.com (2006, July 17). The Amazing Success Story of Infosys. Retrieved from http://www.daijiworld.com/news/news disp.asp?n id=24129\&n tit=The+Amazing+Success+Story+of+Inf osys...

6. Garud R, Kumarswamy, A. \& Malhotra, M. (2003). A passage from India. Stern Business. Retrieved from http://www.stern.nyu.edu/Sternbusiness/spring_summer 2003/passagefromindia.html

7. Handy, F., Kasssam, M. \& Ranade, B. (2007). To profit or not to profit: women entrepreneurs in India, Nonprofit Management and Leadership, 17(4), 383-401.

8. Hero Honda (2007). Hero Honda Motors Informer. Retrieved from http://herohonda.software.informer.com/wiki/

9. Indian Diary (1997). Amul: The complete story. Retrieved from http://www.indiadairy.com/cont highest_milkproducer_amulorigin.html

10. Jauhari, V. (2007). India's preparedness for knowledge based economy: Opportunities and challenges. Journal of Services Research, 7(1), 59-80.

11. Khanna, T. (2004). India's entrepreneurial advantage. McKinsey Quarterly, 2004 Special Edition, 111-114.

12. Khanna T. (2007). Billions of entrepreneurs: How China and India are reshaping their futures and yours. Boston, MA: Harvard Business School Publishing.

13. Lagace, M (2008, January 28). Billions of Entrepreneurs in China and India: Q\&A with Tarun Khanna. Harvard Business School Working Knowledge. Retrieved from http://hbswk.hbs.edu/item/5766.html

14. Miller, K. D. (2007). Risk and rationality in entrepreneurial processes. Strategic Entrepreneurship Journal. 1(1-2). 57-71.

15. Moneycontrol.com (2007, June 11). Amazing story of how Munjal built Hero Honda. Retrieved from http://www.rediff.com/money/2007/jun/11bspec.htm

16. Prabhakar, K. (2011, June 3). Economic and Demographic Forecasting for Business Process Outsourcing Industry in India. Forecasting Models eJournal. 4(12).

17. Ramadorai, S. (2008, April). Emerging entrepreneurial ecosystem in India. Retrieved from http://www.siliconindia.com/guestcontributor/guestarticle/72/Emerging_Entrepreneurial_Ecosystem_in_In dia_S_Ramdorai.html

18. Rawski, T. G. \& Mead, R. W. (1998). On the trail of China's phantom farmers. World Development. 26(5). 767-781.

19. Rediff (2006, July 11). The Amazing Infosys Story. Retrieved from http://specials.rediff.com/money/2006/jul/11sld1.htm

20. SiliconIndia (2011, August 24). India leads global BPO market with 37 percent share. Retrieved from http://www.siliconindia.com/shownews/India_leads_global_BPO_market_with_37_percent_share_Nassco m-nid-89332-cid-3.html

21. Smith, D. (2007). Growling tiger roaring dragon: India, China and the new world order. Vancouver, BC: Douglas \& McIntyre Ltd.

22. Subroto, S. (2011, September 29). Banks can do more to help SME's. Retrieved from http://www.chinadaily.com.cn/cndy/2011-09/29/content_13814651.htm

23. Heing, W. (2012). Chinese economic statistics and figures. Retrieved from http://club.news.sohu.com/rdaily-31453-0-0-0.html

24. Wu, B. \& Knott, A. M. (2006). Entrepreneurial risk and market entry. Management Science. 52 (9). 13151330. 
NOTES 